\title{
Pengaruh Kedisiplinan Belajar Terhadap Hasil Belajar Mahasiswa dalam Mata Kuliah Konsep Dasar IPS
}

\author{
Firosalia Kristin1, Fransiska Faberta Kencana Sari ${ }^{2}$ \\ 1 firosalia.kristin@uksw.edu \\ 1, 2 Universitas Kristen Satya Wacana Salatiga
}

\begin{abstract}
Submitted
June 20, 2019
\end{abstract}

$\begin{array}{cc}\text { Revised } & \text { Accepted } \\ \text { June 24, 2019 } & \text { June 24, 2019 } \\ \text { http://dx.doi.org/10.17509/jpis.v28i1.17810 } & \end{array}$

ABSTRACT

This research is purpose to determine the effect of discipline on collage student learning outcomes in the subject of basic social studies concepts. This type of research is associative research with expost facto design. The subjects of the study were 60 SWCU PGSD students in 2017. The data collection was done through questionnaire and tests. Technique of data analysis is done by linear regression test which includes $t$ test and measurement coefficient of determination. The results showed that 1) The value of $t$ arithmetic 2,904 > the value of $t$ table 1,999, the meaning is that there is an effect of discipline on the learning outcomes of the Student's IPS Basic Concepts;2) R Square value of 0.127 , with the meaning that the influence of the discipline variable on the learning outcomes variable of the IPS Basic Concept of Students is $12.7 \%$. The conclusions through the $t$ tests indicate that there is a disciplinary effect on the learning outcomes of collage students in the IPS Basic Concept course with an effect of $12.7 \%$ which is shown by the measurement coefficient of determination.

Keywords: Discipline of learning, Learning Outcomes of Basic Social Sciences Concepts

\begin{abstract}
ABSTRAK
Penelitian ini bertujuan mengetahui pengaruh kedisiplinan belajar terhadap hasil belajar mahasiswa dalam mata kuliah konsep dasar IPS. Jenis penelitian ini adalah penelitian asosiatif dengan desain expost facto. Subjek penelitian adalah 60 mahasiswa PGSD UKSW angkatan 2017. Pengumpulan data dilakukan melalui angket dan tes. Anaisis data dilakukan dengan teknik uji regresi linier yang mencakup uji $t$ dan pengukuran koefisien determinasi. Hasil penelitian menunjukkan 1) Nilai t hitung 2,904 > nilai t tabel 1,999, maknanya terdapat pengaruh kedisiplinan belajar teradap hasil belajar Konsep Dasar IPS Mahasiswa; 2) Nilai R Square sebesar 0,127, dengan arti bahwa pengaruh variabel kedisiplinan belajar terhadap variabel hasil belajar Konsep Dasar IPS Mahasiswa adalah 12,7\%. Simpulannya melalui uji t menunjukkan adanya pengaruh kedisiplinan tergadap hasi belajar mahasiswa dalam mata kuliah Konsep Dasar IPS dengan pengaruh sebesar 12,7\% yang ditunjukkan melaui hasil pengukuran koefisien determinasi.
\end{abstract}

Keywords: Kedisiplinan Belajar, Hasil Belajar Konsep Dasar IPS

\section{PENDAHULUAN}

Kesadaran akan keharusan melaksanakan aturan yang sudah ditentukan sebelumnya pengajaran tidak mungkin mencapai target yang maksimal [1]. Kesadaran dalam melaksanakan tugas pada hakikatnya merupakan aspek dari kedisiplinan. Disiplin Belajar adalah pengendalian diri mahasiswa terhadap berbagai bentuk aturan baik tertulis maupun tidak tertulis yang telah diterapkan di 
lingkungannya, serta bentuk kesadaran akan tugas dan tanggung jawabnya sebagai pelajar, baik disiplin di rumah atau di kampus dengan tidak melakukan perbuatan yang dapat merugikan tujuan dari proses belajarnya [1].

Pembahasan selanjutnya, target yang hendak dicapai tidak lain adalah kompetensi yang dicapai sebagai wujud dari hasil belajar. hasil belajar merupakan capaian kompetensi pelajar selama dan setelah proses pembelajaran dengan lingkup penilaian hasil belajar mencakup ranah sikap, pengetahuan dan keterampilan.

Kedisiplinan menjadi salah satu faktor yang mempengaruhi hasil belajar [2]. Adanya pengaruh kedisiplinan belajar terhadap hasil belajar mahasiswa bersesuaian dengan hasil penelitian yang menyatakan bahwa terdapat pengaruh positif dan signifikan Disiplin Belajar terhadap Hasil Belajar Mahasiswa Program Studi Pendidikan Akuntansi [1]. Hasil penelitian selanjutnya dilakukan dalam judul "Pengaruh Kreativitas dan Kedisiplinan Mahasiswa Terhadap Hasil Belajar Kalkulus", turut memperoleh hasil bahwa terdapat pengaruh kedisiplinan terhadap hasil belajar mahasiswa [2].

Faktanya terkait dengan kedisiplinan mahasiswa PGSD UKSW yang diperoleh melalui observasi, mahasiswa telah menunjukkan ketepatan waktu dalam mengumpulkan tugas, serta intensitas kehadiran selama perkulian, namun sebagian besar mahasiswa menyatakan masih menerapkan sistem belajar sehari sebelum tes dilaksanakan, serta mengerjakan tugas dua-satu hari sebelum tanggal pengumpulan tugas. Fakta selanjutnya terkait bagaimana hasil belajar mahasiswa, setelah dilakukan penilaian diperoleh hasil belajar mahasiswa berada pada ratarata kelas sebesar 71,58.

Oleh karenanya dengan mempertimbangkan teori serta hasil penelitian sebelumnya diperoleh sebuah hipotesis bahwa kedisiplinan belajar termasuk sebagai faktor yang mempengaruhi hasil belajar, namun muncul keragu-raguan peneliti diantaranya "apakah hasil belajar mahasiswa PGSD UKSW dalam matakuliah Konsep Dasar IPS memang dipengaruhi oleh faktor kedisiplinan?, dan "berapa besar pengaruh kedisiplinan terhadap hasil belajar mahasiswa?", yang mana menjadi latar belakang dilakukannya penelitian dengan judul "Pengaruh Kedisiplinan Belajar terhadap Hasil Belajar Mahasiwa dalam Mata Kuliah Konsep Dasar IPS”.

\section{KAJIAN LITERATUR}

\section{Kedisiplinan Belajar}

Disiplin adalah ketaatan yang berlandaskan pada kesadaran untuk melaksanakan tugas dan kewajiban, serta bertindak sesuai aturan yang berlaku dalam lingkungan tertentu [3]. Individu yang disiplin melakukan suatu kegiatan/tugas dengan teratur oleh karena kesadaran sendiri tanpa adanya paksaan dari pihak lain [4]. Kedisiplinan oleh karenanya diartikan sebagai kesadaran individu terhadap tugas/kewajiban/dan aturan yang nampak pada perilaku individu dalam bagaimana mengendalikan dan mengarahkan diri sesuai aturan yang berlaku di lingkungannya. Maknanya kedisiplinan khususnya kedisiplinan belajar secara lebih lanjut dapat diartikan sebagai pernyataan sikap dan perbuatan siswa/mahasiswa dalam melaksanakan kewajiban belajar secara sadar dengan cara menaati peraturan yang ada di lingkungan sekolah/perguruan tinggi. Pada 
perguruan tinggi kedisiplinan belajar mahasiswa dapat ditinjau dari beberapa aspek diantaranya kedisiplinan mahasiwa dalam mengerjakan tugas, mengumpulkan tugas tepat waktu sesuai kesepakatan, datang lebih awal saat mengikuti perkuliahan, mematuhi peraturan perkuliahan yang sudah disepakati bersama dosen saat kontrak perkuliahan, rajin kuliah tanpa membolos. Kedisiplinan terbagi menjadi tiga indikator, yang pertama perilaku kedisiplinan di dalam kelas, kedua perilaku kedisiplinan diluar kelas, dan yang ketiga perilaku kedisiplinan di rumah [5].

Pertama perilaku kedisiplinan di dalam kelas dapat diartikan saat mengikuti perkuliahan hendaknya mahasiswa memperhatikan apa yang disampaikan oleh dosen, tidak bermainan HP, mengobrol dengan teman, sibuk berdandan dan tidak mengerjakan tugas yang diberikan oleh dosen. Kedua perilaku kedisiplinan di luar kelas dapat diartikan mahasiswa menaati peraturan yang telah ditetapkan di progdi, fakultas mamupun universitas tentang aturan-aturan perkuliahan. Ketiga perilaku displin di rumah, dapat diartikan mahasiwa menaati peraturan-peraturan yang sudah ditentukan dalam keluarga mereka masing-masing. Keluarga membawa pengaruh besar pada diri anak, karena keluarga merupakan cerminan positif dari tingkah laku anak yang dilakukannya dalam kehidupan sehari-hari. Terkait dengan kedisiplinan dalam hal sekecil apapun kita hendaknya menerapkan aturan, memberikan punishmen atau hukuman yang mendidik. Misalnya di rumah diberlakukan peraturan setelah makan piring dan sendok harus dicuci sendirisendiri, ketika bermain harus pulang tepat waktu, tidak boleh terlambat pulang sesuai dengan kesepakatan yang sudah ditentukan. Jika anak melanggar maka perlu diberi hukuman yang mendidik, misalnya uang jajan dikurangi atau hari berikutnya tidak boleh main lagi. Pondasi penerapan kedisiplinan dimulai dari keluarga.

Penanaman sikap disiplin bukan berarti membatasi kebebasan anak akan tetapi merupakan tindakan pengarahan atas apa yang dilakukan anak agar hidupnya teratur dan bertanggung jawab sehingga anak tidak merasa bahwa displin merupakan beban yang harus dia lakukan akan tetapi merupakan suatu kebutuhan bagi dirinya untuk melaksanakan tugasnya sehari-hari [6].

Faktor-faktor yang mempengaruhi kedisplinan siswa yaitu faktor intern dan faktor ekstern [7]. Faktor intern teridir dari faktor pembawaan, faktor kesadaran, faktor minat dan motivasi, dan faktor pengaruh pola pikir. Sedangkan faktor ekstern terdiri dari contoh atau teladan, nasihat, faktor latihan, faktor lingkungan, karena pengaruh kelompok, dan upaya menanamkan disiplin.

Faktor intern, yang pertama pembawaan perilaku anak ditentukan dari pembawaannya [8]. Seseorang mampu bersikap disiplin merupakan warisan dari keturunannya. Keturunan dan lingkungan berpengaruh terhadap sikap atau tingkah laku yang dihasilkan. Yang kedua kesadaran, seseorang yang terbuka dan sadar akan pentingnya disiplin, maka akan melakukannya dengan penuh tanggung jawab karena merasa bahwa aturan atau peraturan yang sudah ditetapkan perlu ditaati agar dapat berjalan dengan baik. Yang ketiga minat dan motivasi, minat adalah harapan, motivasi adalah dorongan. Dalam hal berdisiplin minat dan motivasi 
sangat besar pengaruhnya. Jika seseorang memiliki minat dan motivasi yang tinggi maka dia tidak akan menunggu dorongan dari luar untuk melakukan kedisiplinan. Akan tetapi dia akan melakukan kedisiplinan dengan penuh tanggung jawab. Yang keempat pengaruh pola pikir, perbuatan akan muncul setelah adanya pola pikir. Jika pola pikir kita sejak awal menganggap bahwa disiplin itu penting, maka kita akan melakukan itu dengan baik.

Faktor ekstern, kelima factor tersebut saling mempengaruhi. Teladan, jika kita memberikan contoh atau teladan pada anak untuk dapat menerapkan diplin maka dia akan mengikutinya. Akan tetapi teladan saja terkadang tidak cukup, kita perlu memberikan nasihat atau saran-saran yang berkaitan dengan kedisiplinan. Sikap disiplin yang merupakan pembawaan sejak lahir terkadang juga perlu dikembangkan melalui latihan. Selain latihan faktor lingkungan juga memberikan pengaruh terhadap pelaksanaan disiplin anak. Misalnya lingkungan sekolah atau lingkungan masyarakat. Peraturan yang diterapkan di sekolah juga membawa dampak bagi terlaksananya sikap disiplin anak, akan tetapi jika anak diluar sekolah mempunyai kelompok bermain yang kurang baik atau sebaliknya, itu juga akan mempengaruhi kedisiplinan anak.

Kedisiplinan dapat diupayakan melalui pembiasaan dan contoh atau teladan yang baik sehingga anak akan meniru apa yang dicontohkan.

\section{Hasil Belajar Konsep Dasar IPS}

Hasil belajar merupakan tingkat kompetensi yang telah dicapai seorang individu melalui proses belajar yang pada umumnya ditunjukkan dengan nilai dari aspek pengetahuan, sikap dan keterampilan. Konsep dasar IPS merupakan mata kuliah yang mengkaji tentang konsep-konsep dalam ilmu pengetahuan sosial diantaranya geografi, sejarah, antropologi, sosiologi, psikologi, ekonomi, politik dan hukum [9]. Hasil belajar konsep dasar IPS hakikatnya merupakan tingkat kompetensi mahasiswa dalam mempelajari mata kuliah konsep dasar IPS yang diukur selama dan setelah proses pembelajaran baik dari segi pengetahuan (melalui tes/paham perkuliahan), sikap (selama mengikuti perkuliahan), serta keterampilan (cara belajar mandiri dan cara belajar dalam kelompok). Hasil belajar mempunyai peranan penting dalam proses pembelajaran. Proses penilaian terhadap hasil belajar dapat memberikan informasi kepada pendidik mengenai kemajuan atau kendala mahasiswa dalam upaya mencapai tujuan belajar melalui kegiatan belajar. Melalui informasi tersebut selanjutnya pendidik dapat menyusun dan membina kegiatan-kegiatan mahasiswa lebih lanjut, baik untuk keseluruhan secara klasikal maupun individu [4].

\section{Kajian Hasil Penelitian yang Relevan}

Penelitian dengan judul

"Pengaruh Disiplin Belajar dan Lingkungan Teman Sebaya Terhadap Hasil Belajar Mahasiswa Program Studi Pendidikan Akuntansi Angkatan 2009 Fakultas Ekonomi Universitas Negeri Yogyakarta" pengaruh positif dan signifikan Disiplin Belajar terhadap Hasil Belajar Mahasiswa Program Studi Pendidikan Akuntansi Angkatan 2009 Fakultas Ekonomi Universitas Negeri Yogyakarta yang ditunjukkan dengan nilai $t$ hitung lebih besar dari t tabel yaitu: 7,780 > 1,984 dengan koefisien determinasi sebesar 0,345 yang artinya sebesar $34,5 \%$ variabel ini mempengaruhi Hasil Belajar [1]. 
Pengaruh kedisiplinan belajar terhadap hasil belajar turut dibuktikan melalui penelitian yang dilakukan dalam judul "Pengaruh Kreativitas dan Kedisiplinan Mahasiswa Terhadap Hasil Belajar Kalkulus", dengan hasil bahwa terdapat pengaruh kedisiplinan terhadap hasil belajar mahasiswa yaitu sebesar $1,8 \%$ yang maknaya terdapat pengaruh kedisiplinan namun tidaklah signifikan [2].

Peneliti selanjutnya dalam judul "Pengaruh Motivasi, Metode Pembelajaran dan Disiplin Belajar Terhadap Prestasi Belajar Matematika Teknik di Politeknik Negeri Sriwijaya" turut menyatakan hasil bahwa terdapat pengaruh positif dan disiplin belajar terhadap prestasi belajar, hal ini dipertegas dari analisis koefisien determinasi sebesar $13 \%$ [10].

\section{METODE PENELITIAN}

Jenis penelitian ini adalah penelitian asosiatif dengan desain expost facto. Penelitian ini tergolong penelitian asosiatif karena bertujuan mencari ada tidaknya pengaruh variabel x terhadap y, yaitu kedisiplinan terhadap hasil belajar, adapun desain expost facto oleh karena data diambil apa adanya tanpa adanya perlakuan [4]. Penelitian ini dilakukan pada semester genap tahun ajaran 2018/2019 dengan subjek penelitian adalah 60 mahasiswa Pendidikan Guru Sekolah Dasar, Fakultas Keguruan dan Ilmu Pendidikan, Universitas Kristen Satya Wacana Salatiga angkatan 2017. Pengumpulan data diperoleh melalui angket dan tes. Teknik analisis data dalam penelitian ini dilakukan dengan uji regresi linier melalui teknik uji $\mathrm{t}$ dan pengukuran koefisien determinasi.

\section{HASIL DAN PEMBAHASAN}

Hasil analisis data melalui uji regresi linier dengan teknik uji $t$ dan pengukuran koefisien determinasi diuraikan dalam tabel 4.1 dan 4.2 diantaranya:

Tabel 4.1 Hasil Uji t

\begin{tabular}{|c|c|c|c|c|c|}
\hline \multicolumn{6}{|c|}{ Coefficients $^{\mathrm{a}}$} \\
\hline \multirow{3}{*}{ Model } & Unsta & ndardized & Standardized & \multirow{3}{*}{$\mathrm{T}$} & \multirow{3}{*}{ Sig } \\
\hline & \multicolumn{2}{|c|}{ Coefficients } & Coefficients & & \\
\hline & B & Std. Error & Beta & & \\
\hline (Constant) & 42,240 & 10,128 & & 4,171 & , 000 \\
\hline Kedisiplinan &, 360 & 124 &, 356 & 2,904 & ,005 \\
\hline
\end{tabular}

A. Dependent Variable: HASILBELAJAR

Tabel 4.2 Hasil Pengukuran Koefisien Determinasi

\begin{tabular}{|c|c|c|c|c|c|}
\hline \multicolumn{6}{|c|}{ Model Summaryb } \\
\hline $\begin{array}{l}\text { Mo } \\
\text { del }\end{array}$ & $R$ & $\begin{array}{c}\mathrm{R} \\
\text { Squar } \\
\mathrm{e}\end{array}$ & $\begin{array}{c}\text { Adjust } \\
\text { ed } R \\
\text { Squar } \\
\mathrm{e} \\
\end{array}$ & $\begin{array}{c}\text { Std. } \\
\text { Error of } \\
\text { the } \\
\text { Estimate }\end{array}$ & $\begin{array}{l}\text { Durbin- } \\
\text { Watson }\end{array}$ \\
\hline 1 & $356^{\mathrm{s}}$ & 127 & 112 & 5,399 & 2,408 \\
\hline \multicolumn{6}{|c|}{ a. Predictors: (Constant), KEDISIPLINAN } \\
\hline
\end{tabular}

Dari tabel 4.1 diperoleh nilai $t$ hitung adalah 2,904 > dari nilai t tabel yaitu 1,999, maknanya maknanya terdapat pengaruh kedisiplinan terhadap hasil belajar Konsep Dasar IPS Mahasiswa, selanjutnya pada tabel 4.2 menunjukkan Nilai $\mathrm{R}$ Square sebesar 0,127 , yang berarti bahwa pengaruh variabel kedisiplinan belajar terhadap variabel hasil belajar Konsep Dasar IPS Mahasiswa adalah 12,7\%.

Adanya pengaruh kedisiplinan belajar terhadap hasil belajar, sejalan dengan hasil penlitian refrensi [1] yang menyatakan terdapat pengaruh positif Disiplin Belajar terhadap Hasil Belajar Mahasiswa Program Studi Pendidikan Akuntansi Angkatan 2009 Fakultas Ekonomi Universitas Negeri Yogyakarta .

Hasil penelitian ini bahwa terdapat pengaruh kedisiplinan terhadap hasil belajar turut bersesuain 
dengan hasil penelitian dimana terdapat pengaruh kedisiplinan terhadap hasil belajar Kalkulus mahasiswa [2].

Namun terkait seberapa besar pengaruh kedisiplinan terhadap hasil belajar, dari hasil penelitian ini diperoleh hasil bahwa pengaruh kedisiplinan belajar terhadap hasil belajar dalam mata kuliah Konsep Dasar IPS tidaklah signifikan dengan persentase 12,7, maknanya terdapat $87,3 \%$ faktor lain yang mentukan hasil belajar mahasiswa selain kedisiplinan. Tidak signifikannya pengaruh kedisiplinan ini menyimpulkan bahwa pengaruh kedisiplinan tidaklah signifikan yaitu sebesar $1,8 \%$ [3]. Bertolak belakang dengan hasil penelitian yang menyatakan bahwa besar pengaruh kedisiplinan adalah signifikan dengan persentase 34,5 [1].

Faktor lain yang diduga dapat mempengaruhi hasil belajar mahasiswa dalam mata Kuliah Konsep Dasar IPS adalah motivasi belajar dan cara belajar mahasiswa sering kita sebut "SKS" yaitu sistem kebut semalam. Mahasiswa hanya akan belajar saat ada tugas dan tes. Belajar yang dilakukannya pun tidak secar kontinyu tetapi sehari sebelum tes baru belajar. Selain itu sesuai dengan penjelasan di kajian teori, kedisiplinan itu juga dipengaruhi oleh kelompok. Pengaruh kelompok bermain juga sangat riskan. Jika mahasiwa mempunyai kelompok bermain yang baik, yang taat terhadap peraturan yang telah ditetapkan, maka dia akan menjalankannya dengan baik dan tanggung jawab. Atau sebaliknya jika mahasiswa mempunyai kelompok bermain yang sering melanggar peraturan yang telah ditetapkan, maka kedisiplinan itu tidak pernah diperhatikannya.

\section{SIMPULAN}

Melalui uji $\mathrm{t}$ diperoleh $\mathrm{t}$ hitung adalah 2,904 lebih besar dari nilai t tabel yaitu 1,999, yang menunjukkan makna bahwa adanya pengaruh kedisiplinan tergadap hasil belajar mahasiswa dalam mata kuliah Konsep Dasar IPS, dengan pengaruh sebesar $12,7 \%$ yang ditunjukkan melaui hasil pengukuran koefisien determinasi.

\section{REKOMENDASI}

Beberapa saran bagi para pemangku kepentingan berdasarkan hasil penelitian ini adiantaranya; 1) bagi Mahasiswa, dari penelitian ini telah terbukti jika kedisiplinan belajar mempengaruhi hasil belajar, walaupun besarnya pengaruhnya tidaklah signifikan namun kedisiplinan terbukti menjadi salah satu faktor yang mempengaruhi hasil belajar. Oleh karenanya mahasiswa perlu menerapkan kedisiplinan belajar sebagai kesadaran yang timbul dari dalam diri sebagai sebuah bentuk kebiasaan belajar yang dilakukan secara rutin, agar mencapai hasil belajar yang maksimal.

2) Bagi Dosen, dosen dapat memberikan bimbingan dan teladan akan bagaimana perilaku disiplin belajar, selanjutnya dosen juga dapat memberikan reward pada mahasiswa yang mampunyai disiplin belajar dan punishment bagi mahasiswa yang tidak displin dalam belajar agar timbul kesadaran dalam diri mahasiswa bagaimana seharusnya bertindak disiplin.

3) Bagi Peneliti Selanjutnya, dari penelitian ini diperoleh hasil jika pengaruh kedisiplinan belajar terhadap hasil belajar mahasiwa sebesar $12,7 \%$, hal ini menunjukkan jika terdapat $87,3 \%$ faktor lain yang mempengaruhi hasil belajar. Oleh karenanya bagi peneliti 
selanjutnya dapat meneliti apakah faktor-faktor selain kedisiplinan yang mempengaruhi hasil belajar, misalnya faktor internal (kondisi jasmani, intelektual, psikologis, bakat, minat) ataupun faktor eksternal (keluarga, perguruan tinggi, masyarakat).

\section{DAFTAR PUSTAKA}

[1] S. T. P. Saputro, "Pengaruh Disiplin Belajar dan Lingkungan Teman Sebaya Terhadap Prestasi Belajar Mahasiswa Program Studi Pendidikan Akuntansi Angkatan 2009 Fakultas Ekonomi Universitas Negeri Yogyakarta," J. Pendidik. Akutansi Indones., vol. 10, no. 1, pp. 78-97, 2012.

[2] M. Nurfitriyani, "Pengaruh Kreativitas dan Kedisiplinan Mahasiswa Terhadap Hasil Belajar Kalkulus," J. Form., vol. 4, no. 3, pp. 219-226, 2014.

[3] H. W. J. Wadi, "Hubungan Kedisiplinan Belajar Siswa dengan Hasil Belajar Pada Mata Pelajaran Teknik Las Dasar di SMK Muhammadiyah 1 Padang," J. Pendidik. Tek. Mesin, 2016.

[4] M. M. Sobri, "Pengaruh Kedisiplinan dan Kemandirian Belajar Terhadap Hasil Belajar Ekonomi Madrasah Aliyah Di
Kecamatan Praya," J. Harmon. Sos., vol. 1, no. 1, pp. 43-56, 2014.

[5] M. Khafid, "Pengaruh disiplin belajar dan lingkungan keluarga terhadap hasil belajar ekonomi," Din. Pendidik., vol. 2, no. 2, 2007.

[6] M. Nurfitriyanti, "Pengaruh Kreativitas Dan Kedisiplinan Mahasiswa," Form. J. Ilm. Pendidik. MIPA, vol. 4, no. 3, pp. 219-226, 2014.

[7] W. A. Kurniawan, Budaya Tertib Siswa Di Sekolah (Penguatan Pendidikan Karakter Siswa). Jawa Barat: CV Jejak, 2018.

[8] P. Kedisiplinan dan Kemandirian Belajar Muhammad Sobri et al., "the Effect of Discipline and Autonomy Learning on the Learning Achievement in Economics Subject," J. Harmon. Sos., vol. 1, no. 1, pp. 43-56, 2014.

[9] N. Sumaatmaja, Konsep dasar IPS SD. Jakarta: Universitas Terbuka, 2010.

[10] I. Maja, "Pengaruh Motivasi, Metode Pembelajaran dan Disiplin Belajar Terhadap Prestasi Belajar Matematika Teknik di Politeknik Negeri Sriwijaya," J. Orasi Bisnis, vol. 9, no. 3, pp. 1-10, 2013. 